\title{
Community-focused strategies
}

\author{
Andrea Fosfuri \\ Universidad Carlos III de Madrid, Spain \\ Marco S. Giarratana \\ Universitá Bocconi, CROMA, Italy and Universidad Carlos III de Madrid, Spain
}

\section{Esther Roca}

Universidad Carlos III de Madrid, Spain

\begin{abstract}
This article introduces the notion of community-focused strategies to refer to the set of actions, activities and policies that firms undertake to establish connections or relational links with one or more target communities of (potential) customers. Drawing on social identity theory and strategy research, this study begins with a proposed taxonomy of different community-focused strategies. Then it illustrates how such strategies contribute to the creation of competitive advantage and explores their boundary conditions. Finally, the authors offer implications for theory development and practice, as well as suggestions for further research.
\end{abstract}

\section{Keywords}

communities, competitive advantage, firm strategies, identity

We call ourselves a tribe. ... There is a real sense of community when it comes to surfing, and it's great to see kids I've known since they were in grammar school become better at the sport. (Testimonial from a New England surfer; Edges, 2010)

\section{Introduction}

Many surfers consider themselves members of a particular tribe (Lanagan, 2009; Taylor, 2007) that uses neologisms, such as the exclamation 'cowabunga!' (how are you doing?) or references to being 'stoked' (feeling joy or ecstasy); follows rituals, such as rising early to greet the sun and the waves or collectively attending surf film screenings; wears clothing covered with symbolic objects (e.g. surfboards) or Hawaiian shirts; and marks homes and automobiles with surf symbols and slogans (Taylor, 2007). Undoubtedly these surfers constitute a rather peculiar community for whom surfing takes on near religious connotations, such that 'For most of my life it seemed that religious ideals were nothing more than conjecture, but then I started surfing' (Taylor, 2007: 939). 
But they are also exemplars of an interesting social phenomenon, that is, the propensity of people to come together in social groups or communities primarily to satisfy their needs for sense and identity. As prominent scholars from different fields have suggested (Gergen, 1991; Kumar, 2005; Lyotard, 1984; Vattimo, 1992), this tendency has even accelerated in recent decades, characterized by incredulity towards traditional values and greater demand for heterogeneous sources of meaning. Starting with the canonical study by Tajfel and Turner (1979), social identity theory has postulated that when a person sees him- or herself as a part of a group, he or she derives self-esteem from that group membership and adopts behaviours consistent with the stereotypes associated with the group's identity (Shih et al., 1999). Examples of communities as providers of identity are disparate, spanning the rock climbing community with its own slang, dress code and values (Harrison and Corley, 2010); environmental movements (Hoffman and Bertels, 2010); football clubs in Europe; and the Harley Owners Group (Fournier, 1998).

Firms increasingly recognize the potential opportunities of interactions with social groups or communities, which often provide reservoirs of potential customers. Companies such as Quicksilver, Billabong and O’Neill have established, from early in their existence, a close relationship with the surfer community, to which they sell surfwear and related equipment (Lanagan, 2009). Patagonia, a California-based company focused mainly on outdoor clothing, is a member of and major contributor to several environmental movements. For example, it funds activists who take radical and strategic steps to protect habitat, wilderness and biodiversity (Forest et al., 2003). Recently, Harrison and Corley (2010) have explored the dynamics between Alpinista (a pseudonym) and the communities of rock climbers and skiers to which most of the firm's customers belong.

Inspired by these observations, we seek a better understanding of this phenomenon from a strategy viewpoint. Accordingly, we introduce the notion of 'community-focused strategies' (CFS), which we define as the actions, activities and policies that a focal firm undertakes to establish connections or relational links with one or more target communities of (potential) customers. Drawing on both social identity theory and strategy research, we propose a theoretical framework to investigate this phenomenon. First, we offer a taxonomy that classifies CFS according to two dimensions: (1) the congruence between the focal firm's supported values and those of the target community(ies) and (2) the power of the focal firm to influence the identities of the target community(ies). Second, we explore how different types of CFS contribute to the creation of competitive advantage and analyse the specificities and sustainability of this competitive advantage across the range of CFS included in our taxonomy. Third, we investigate the disadvantages of each CFS approach by highlighting its associated boundary conditions.

A peculiar feature of our framework is that we perform our analysis at the firm-community level. Therefore, the ultimate target of firm endeavours is a given community (or set of communities). We define community as any social group in which perceived membership offers a sense of identity to the individuals who see themselves as a part of that community (Calvano, 2008; McAlexander et al., 2002; Tajfel and Turner, 1979). ${ }^{1}$ Key to our analysis is the assumption that a significant fraction of (potential) customers of a focal company are members of communities that provide them a shared identity. This association might result from coincidence, such as when several members of a community happen to purchase from the focal firm, or it might reflect a deliberate decision by the company to include community members in its target market.

The interactions between companies and communities have been considered in different streams of management research, though rarely from a strategy viewpoint. In particular, a considerable body of work investigates the actions firms take to respond and adapt to external pressures and thus gain legitimacy (Combs et al., 2009; Di Maggio and Powell, 1983; Scott, 2005). Within this 
tradition, several scholars have employed institutional theory to study how firms and communities interact (Calvano, 2008; Julian et al., 2008; Marquis et al., 2007). Whereas traditional institutional theory views firms as passive receptors of institutional norms, recent advances, including those produced by the institutional entrepreneurship school of thought, suggest that organizations also might embed new meanings and thus change the institutional context (Greenwood and Suddaby, 2006; Munir and Philips, 2005). From a slightly different perspective, other authors explore the interactions and frictions between corporations and political and social movements (e.g. King and Soule, 2007), noting that though most firms simply adapt and adjust (Ingram et al., 2010), others resist or react (Briscoe and Safford, 2008). Our framework builds on these premises to provide a more nuanced picture of how firm-community dynamics generate relationship-based intangible assets that might set the foundation for a competitive advantage.

In addition, stakeholder theory refers to the interactions between stakeholders, defined as 'any group or individual who can affect or is affected by the achievement of the organization's objectives' (Freeman, 1984: 46), and the company. Stakeholder theory (Donaldson and Preston, 1995; Freeman, 1984; Frooman, 1999) recognizes the importance of communities but treats them as 'a default, a sort of error term containing all sorts of interests and externalities that fail to find homes with customer, supplier, employee, or shareholder groups' (Dunham et al., 2006: 24). In our proposed framework, the community represents both a level of analysis, distinct from the classical representation of customers as a stakeholder group, and a point of reference for the focal firm. We thus provide a narrower but deeper perspective of firm-community dynamics by focusing only on those interactions that support an identity-based link.

Our work benefits from insights achieved in branding and marketing research interested in the process of consumer identification with a specific brand and the development of so-called brand communities (Cova and Cova, 2002; McAlexander et al., 2002; Muniz and O’Guinn, 2001). These social groups consist of admirers of a brand, whose identity depends primarily on either the brand or their consumption activities, such that their meaning gets negotiated through marketplace symbols (McAlexander et al., 2002; Schouten and McAlexander 1995). Brand community research mostly explores firm-community links to achieve a better understanding of customer behaviour (Algesheimer et al., 2005) and the social aspects of consumption (Arnould and Thompson, 2005; Schouten et al., 2007), as well as to operationalize the link between consumers and the firm (Schau et al., 2009). We instead address the linkages between identity creation, community and firm strategy in our attempt to investigate the implications of community-firm dynamics for competitive advantage. Thus, the focus of our analysis moves from the marketing function to the overall business strategy (Fournier and Lee, 2009). Moreover and in line with Holt (2002), we consider communities providers of identity in broader terms, such that our analysis encompasses communities that exist independently of a focal firm or brand. Our theory thus applies to domains in which the grounds of identification are not represented exclusively by brands; as we explain in greater detail subsequently, brand communities are relevant only for a subset of our CFS taxonomy.

\section{Identity and communities}

The term 'community' appears in social science research in a broad sense to refer to any group in which members share common conditions (Cow and Allan, 1994; Lee and Newby, 1983), such as specific needs (e.g. health), shared interests (e.g. sexual orientation), or common geographical locations (e.g. neighbourhood). Some authors narrow the definition further by arguing that the key feature of a community is attachment or a sense of belonging, because not all communities provide a sense of shared identity (Cohen, 1982). We follow this tradition and consider community any 
social group characterized by a shared identity. The role of communities as identity providers has increased in recent decades, probably due to social transformations in western contemporary society (Castells, 2000; Gergen, 1991; Kumar, 2005; Lyotard, 1984).

Social identity theory (Tajfel and Turner, 1979) is a particularly useful platform for understanding how and why people obtain a sense of identity from their perceived membership in communities. When a person regards him- or herself as a part of a community, he or she derives self-esteem from that membership and adopts behaviours consistent with stereotypes associated with the community's identity (Shih et al., 1999), through the processes of categorization, identification and comparison. Categorization occurs when a person decides to join a community with specific characteristics that help define his or her self-perception (Hogg and Terry, 2000), whereas identification is the process of identity formation through active community participation, which shapes the boundaries between inside and outside the community (Cohen, 1985). Thus individuals become category representatives or cognitive representations of the community, which contain its meanings, values and norms (Hogg and Terry, 2000). Finally, through comparison, a person can compare and exploit his or her community membership to derive a form of social differentiation, which reinforces perceived similarities between in-group members and accentuates perceived differences with respect to out-group members (Stets and Burke, 2000).

Social identity research shows that persons who take on a community-based identity reveal a certain degree of uniformity in their perceptions and actions, perhaps through social stereotyping (i.e. community identification enhances stereotyped perceptions), positive evaluations of other community members, greater commitment to and less desire to quit the community, or enhanced participation in social activities (Stets and Burke, 2000).

\section{Identification through values and symbols}

Community values and symbols are necessary constructs to understand the categorizationidentification-comparison process, and they represent critical building blocks for the design of CFS. Social identity theory research suggests that a community's degree of cohesion and the intensity of the identity provided to members depend on the distinctiveness of its founding values, relative to those of other communities (Ashforth and Mael, 1989). Because values are difficult to observe, people represent the defining and stereotypical values of a community in the form of symbols (Hogg and Terry, 2000).

Research into values spans several social science disciplines with unique conceptualizations and different angles (Hitlin and Pilavin, 2004). We mainly draw on Schwartz’s (1994: 21) conceptualization of values as 'desirable transituational goals, varying in importance that serve . . a as guiding principles in the life of a person or other social entity'. These goals synthesize 'affective and cognitive elements to orient people to the world in which they live' (Marini, 2000: 2828).

Values are also central to the development and preservation of social identity (Hitlin, 2003; Taylor, 1989) and thus represent the primary dimension that configures communities as providers of identity. People experience communal values, which are socially patterned, as unique to themselves, which implies a sense of both individual autonomy and communal involvement (Smith, 1991). In this sense, values enable categorization (Turner and Tajfel, 1986) and help establish the boundaries of a community (Rowley and Moldoveanu, 2003), which supports the identification process. The distinctiveness of the values of a given community, in relation to those of comparable communities, helps differentiate ‘figure from ground' and provide a unique identity (Ashforth and Mael, 1989). 
Communities manifest their core values through symbols, which facilitate the transmission of identity to members. Symbols, such as slogans, rituals, policies, products, or behaviours shared by members, can make membership salient and provide compelling images of what the community represents (Ashforth and Mael, 1989). The symbols of the community thus are instrumental for defining its boundaries and differentiating it from non-community members or other communities. They also enable the process of comparison by supporting prototype-based depersonalization that produces social identity phenomena (Hogg and Terry, 2000). When a community's symbols are more distinctive, the community provides a stronger identity (Ashforth and Mael, 1989; Hogg and Terry, 2000; Rowley and Moldoveanu, 2003).

Whereas values and symbols explain identity formation in a community, through categorization and social comparison, identification with a community generates intra-group favouritism, cooperation, trust, altruism and loyalty (Heckathorn, 1996; Turner and Tajfel, 1986) - social behaviours consistent with the notion that people exert personal effort and engage in non-stipulated actions to reciprocate the community's identity provision (Anthony, 2005; Heckathorn, 1996; Turner and Tajfel, 1986). Community members reciprocate because they expect others to act in ways that reinforce the community identity or believe they must reward others for contributing. Donations and participation in community events offer archetypal examples of reciprocal behaviours by community members. Thus members of surfing communities reciprocate the provision of identity with unpaid efforts to organize events or communicate weather, sea and tide conditions. Values and symbols are antecedents of community-member identification (Ashforth and Mael, 1989); reciprocity is an expected outcome.

\section{Communities and strategy}

\section{Reframing CFS: A new taxonomy}

We define community-focused strategies (CFS) as the actions, activities and policies that a focal firm $(f)$ undertakes to establish connections or relational links with one or more target communities (c) of (potential) customers $(f \rightarrow c)$. We propose a taxonomy of such strategies and illustrate in detail how they might lead to competitive advantage. For our proposed taxonomy, we define CFS according to two dimensions that represent the ex ante conditions of a strategic decision, that is, before deciding on the strategy approach and before the implications of this decision unfold.

The first is the congruence between the focal firm's supported values and those of the target community. As we explained previously, values and their distinctiveness enable communitymember identification (Ashforth and Mael, 1989) and thus constitute a critical dimension to assess different community-focused approaches. At the highest level of congruence, the focal firm shares and supports values that perfectly coincide with those of the target community, such that the firm's identities and the community's identities correspond to and reinforce each other. At the lowest level of congruence, the values the focal firm supports and invests in differ from but are not necessarily in conflict with those of the target community.

The second dimension refers to the power of the focal firm to influence the identities of the target community. At one extreme, a company might exert a high degree of control over the target community's identities by credibly committing to values that provide identification (Selznick, 1957). Strong commitment to values is a necessary, if not sufficient, condition to exert power over the community's identities. As strategy research has shown, commitment is more credible and effective in contexts marked by high choice (i.e. when alternative values are available), high irreversibility (it is costly to change) and high visibility (it is highly public) (Danneels, 2003; Salancik, 


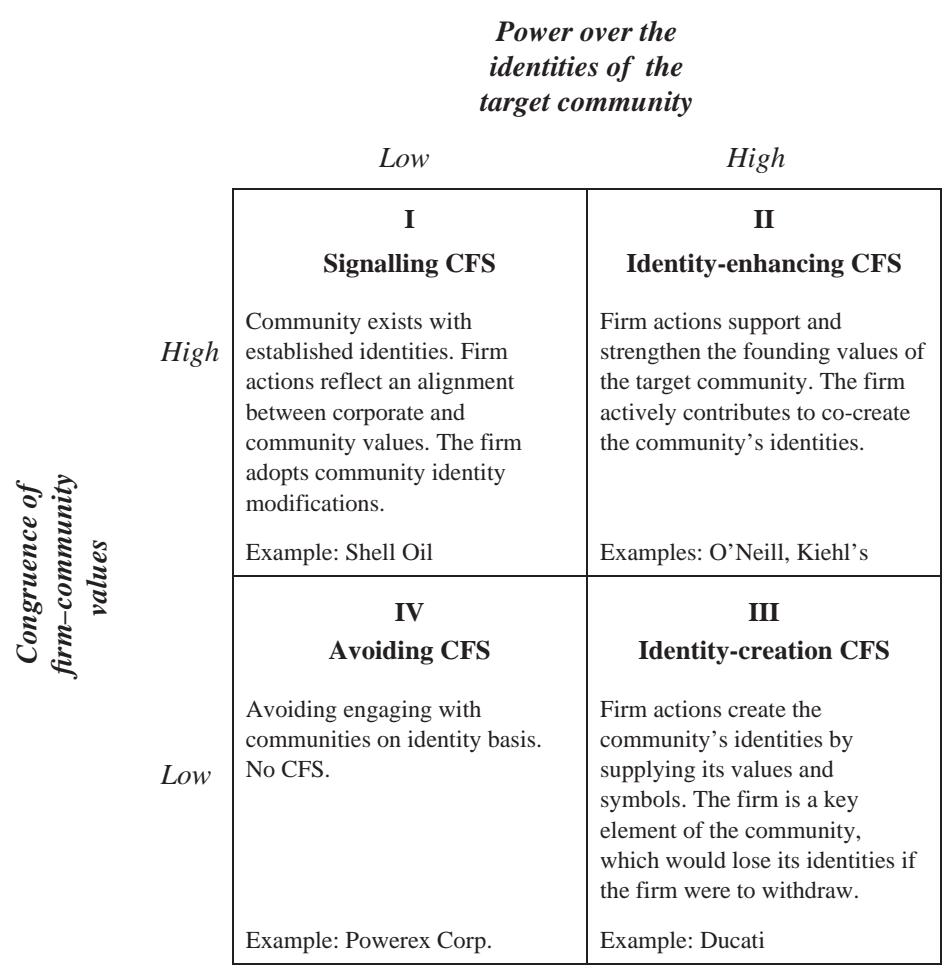

Figure I. Taxonomy of community-focus strategies (CFS)

1977; Weick, 1995). Companies thus might act as identity providers, as noted in organization theory (O’Reilly et al., 1991) and marketing literature (Bhattacharya and Sen, 2003), though not in previous strategy research. At the other extreme, the focal firm does not or cannot influence the identities of the target community and thus has no power over them.

In Figure 1, we use these two dimensions to obtain a taxonomy of CFS that comprises four quadrants: (1) high congruence/low power, (2) high congruence/high power, (3) low congruence/ high power and (4) low congruence/low power. We associate each quadrant with a specific form of CFS: signalling, identity-enhancing, identity-creation and avoiding.

Signalling CFS are adaptive by nature and attempt to align corporate and community values. These strategies include investments in empathic behaviours and postures, as well as actions that help fine-tune the focal firm's image in accordance with values that provide identity to community members (e.g. philanthropic donations to environmental causes). With a signalling CFS, a firm gains legitimacy as a member of a given community, or at least is not deliberately excluded from that community. However, signalling CFS are characterized by a weak commitment to the community's values and a low level of control over the target community's identities, which makes them unlikely to trigger non-trivial levels of reciprocity. For example, the Anglo-Dutch company Shell Oil has undertaken several well-advertised initiatives (e.g. the Eco-marathon, an international competition of high school and college student teams to design, build and test 
energy-efficient vehicles) that reflect the congruence between its supported values and those of target communities. However, the company has almost no control, nor attempts to gain it, over the pre-existing identities of those communities.

Identity-enhancing CFS are characterized by a relatively deep integration between the focal firm and a target community. The firm's actions and investments work actively to expand or strengthen the values of the target community, leading to high congruence between the supported values and those that provide identification to community members. Such congruence implies the firm and community participate in identity co-creation $(f \leftarrow \rightarrow c)$. The firm's strong commitment to the target community's values usually is manifest in a stable pattern of actions and interventions (Salancik, 1977; Weick, 1995), such as meetings and social events organized by the firm that instil enthusiasm and a sense of belonging (Fireman and Gamson, 1979). These activities strengthen both the perception of shared values and the power of symbols, because values get evoked across a broader set of situations, and symbols become more visible (Laraña et al., 1994). As Mullen et al. (1992: 105) assert, 'factors which direct people's attention towards their own group are likely to enhance in-group members' awareness of in-group attributes' and thereby stimulate identification (Tajfel and Turner, 1979). O'Neill, the US surfwear and equipment brand, provides a good example: it routinely sponsors surf events, contests and beach-cleaning days. Kiehl's, a US cosmetic producer and retailer, appeals to its customers by raising money for Heritage of Pride, a nonprofit group that organizes lesbian, gay, bisexual and transgender pride activities in New York.

Identity-creation CFS differ from identity-enhancing CFS because they require the focal firm to provide, through a set of well-synchronized actions, new or largely modified identities to its customers (Holt, 2002). Although the ex ante congruence between the supported and the target community's values is low, ex post the company becomes the main source of values for the community that arises around these new identities. Typically these new identities are firm-centric, so the community would stop providing any sense of identity if the firm were to withdraw. The company has thus strong power to influence the community's identities. A key feature of identity-creation CFS is the active role of the firm in connecting community members, such as by organizing and sponsoring meetings or events in its facilities, stores, or public spaces, as in the familiar examples of Ducati, Harley-Davidson and Piaggio. Marketing literature has also considered identitybased links to customers; several authors use the concept of brand communities to refer to 'specialized, non-geographically bounded communit[ies] based on a structured set of social relationships among admirers of a brand' (Muniz and O’Guinn, 2001: 412). In such communities, identity depends on either brands or consumption activities (Algesheimer et al., 2005; Arnould and Thompson, 2005; Schouten et al., 2007), and the symbols of the marketplace determine meaning (McAlexander et al., 2002; Schouten and McAlexander, 1995). Bhattacharya and Sen (2003) further suggest that consumers might identify with a company - not just its brand - to satisfy their self-definitional needs (Ashforth and Mael, 1989). Finally, it is worth noting that we use the label 'identity-creation CFS' to stress the strategic viewpoint of our taxonomy and differentiate our analysis from the prevailing marketing-oriented approach in brand community and customer-firm identification literature (Fournier and Lee, 2009).

Avoiding CFS means no CFS. The focal firm does not engage with communities on an identity basis, because its supported values do not overlap with those of the target communities, and it cannot expect to achieve congruence ex post because it has no control over communities' identities. Powerex, a leader in energy markets across North America, focuses on 'securing and moving energy and [tries to] reliably deliver energy products', with no attempt to engage with environmental groups that might be part of its customer base (see www2.powerex.com/AboutUs.aspx). 


\section{CFS, competitive advantages and disadvantages}

By definition, CFS aim to establish a relational link between the focal company and the target community $(f \leftarrow \rightarrow c)$. Broadly speaking, the resulting relationship-based intangible assets are specific and idiosyncratic to the interaction between the focal firm and the target community (Wood and Jones, 1995), which suggests that they represent a potential source of competitive advantage (Zucker, 1986). We therefore explore the properties of resources (valuable, rare, difficult to imitate and non-substitutable) that each community-focused approach generates to assess their potential to lead to competitive advantages (Barney, 1991).

Signalling CFS. Community members scrutinize and evaluate the firm's actions, and if those actions conform to and respect the values of the target community, the firm can secure a positive assessment, which helps it gain legitimacy, community membership and ultimately reputational capital (Dutton et al., 1994; Gardberg and Fombrun, 2006). Reputational capital is thus the key resource arising from the implementation of signalling CFS. Community members likely have positive feelings about being associated with the firm and are more willing to cooperate with it (Wang et al., 2008). In addition, reputational capital disposes community members to hold beliefs about the firm that influence their actions, such that firms might buffer against negative shocks (Godfrey, 2005) and insulate themselves from consumer boycotts or discrimination (Barnett and Salomon, 2006).

Godfrey (2005) and Wang et al. (2008) propose that corporate philanthropy can generate positive reputational capital when the philanthropic activity is consistent with a community's values. Lev et al. (2010) also show that corporate philanthropy advances firms' economic objectives, which implies a potential link between signalling CFS and competitive advantage.

These arguments suggest that the reputational capital created by signalling CFS is a valuable resource; it is also rare because it is based on a relational link with the target community that unfolds across time. However, because the focal firm's power to influence the community's identities is weak, the resulting reputational capital is easy to imitate and can be replicated by other firms through alternative channels. This characteristic constitutes an important disadvantage of this kind of CFS; thus an advertising campaign by Shell trumpeting its support of green initiatives can easily be matched by Exxon if it were to release an eco-friendly, energy-saving motor oil. In addition, customers do not feel an obligation to reciprocate, which offers fewer opportunities to build a differentiation advantage.

As its key success factor though, signalling CFS requires the firm to display credibility and authenticity (Keller and Aaker, 1998), which constitutes a strong basis for a firm-community relationship. This ability (or its lack) defines an essential advantage (disadvantage) of signalling CFS. Community members must perceive the firm's actions as genuine manifestations (Gordon, 1996; Holt, 2002). If the firm's value-based investments instead appear instrumental or hypocritical, community-focused actions can produce mixed effects or even hostility from targeted communities. BP offers an excellent example. Even before the 2010 Gulf of Mexico oil spill, environmental organizations regularly lambasted BP for associating itself with the values of their community while simultaneously engaging in environmentally unsafe practices. More than a decade ago, a Greenpeace organizer thus complained, 'BP promotes itself as a green oil company concerned about global warming, yet continues to drill in new oil frontiers. . . . It's time for BP to put its money where its mouth is' (Business Wire, 2000: 1640).

Identity-enhancing CFS. Because the firm's commitment to community values is stronger, more visible, specific and evoked across a broader set of activities (Danneels, 2003; Weick, 1995), 
identity-enhancing CFS deliver greater levels of legitimacy, community membership and reputational capital than signalling CFS. These relationship-based intangible assets are both valuable and rare, but also more difficult to imitate or substitute, in that they result from a specific, deeper integration between the focal firm and the target community, which unfolds across time, is idiosyncratic and path-dependent (Barney, 1991). Moreover, because the firm contributes to the community's shared identity by strengthening its values, community members likely feel obliged to reciprocate (Ashforth and Mael, 1989). The firm can exploit this urge through two main channels: information access, which leads to customization, and the association between products and symbols.

For example, firms can leverage the reciprocity mechanism triggered by their identity-enhancing CFS to gain access to privileged information about community members' preferences, then employ this information to develop products that better match their customers' expectations. In marketing literature, this process is known as customer co-creation, or 'a collaborative new product development activity in which consumers actively contribute and select various elements of a new product offering' (O’Hern and Rindfleisch, 2009; see also Etgar, 2008). Alternatively, the company might exploit its privileged position among community members to configure its products as elements of their symbology, such that the firm's products become manifestations of community values, to which the company already has demonstrated its strong commitment. For example, a Patagonia jacket may signal the wearer's individual association with the community of environmentally concerned hikers. In this case, the consumer acquires the product/symbol not only for its capacity to satisfy functional needs but also for its community identification content. This association between firm products and community symbols encourages fidelity and a willingness to pay a premium, such that the firm can capture higher margins from products that achieve community symbolic status.

Both privileged access to customers' information and the symbolic meaning of the product portfolio are crucial resources to establish a product differentiation advantage: they are valuable (for designing optimal product portfolios), rare (the information is difficult to access and symbols are not easy to establish) and difficult to imitate (because they result from a path-dependent, idiosyncratic, long-term relationship). However, the non-substitutability trait could be dual sided. Access to customer information might be more substitutable, because other firms can customize their product offerings or launch products that satisfy new community needs using other marketing techniques (i.e. parallel product launches). Yet the symbolic meaning of the product portfolio clearly is difficult to substitute.

One of the key disadvantages of identity-enhancing CFS is that they establish a strong association between the focal firm and the target community, which might become a drawback as the set of core values that grant community members their shared identity evolves and changes over time (Godfrey, 2005; Palazzo and Basu, 2007). A firm-community association thus might entrap a company with values that it does not share and support, which could trigger de-identification by customers (Elsbach and Bhattacharya, 2001), a loss of legitimacy, or restricted access to other relevant resources. A firm engaged in identity-based links with environmental groups, for example, thus might suffer if the broader public believes it is also associated with the Earth Liberation Front, an activist group that claimed responsibility for destroying a suite of offices in Michigan State University's Agriculture Hall because of the programme's ties to biotechnology (Hoffman and Bertels, 2010).

Identity-creation CFS. The competitive advantage derived from identity-creation CFS results from the close firm-community interdependence that provides increased customer loyalty and thus 
higher switching costs. This derivation occurs through different identity-based mechanisms (Homburg et al., 2009). First, loyalty by members validates and reinforces their feeling of belonging to the community, because the products and services purchased are both symbols and values of that community. Second, reciprocity implies loyalty, in that customers pay the company back for the identity they have received, through repeated purchases and positive word of mouth. Third, because the company constitutes the shared identity of the community the customer uses to fulfil self-definitional needs, he or she cannot switch, even if other firms offer better deals (Bhattacharya and Sen, 2003). These loyal, unswitching customers likely buy more, pay higher prices, recommend the firm's products and services to others and adopt new products and upgrades. Owners of Harley-Davidson, Vespa, or Ducati motorcycles are often fanatical devotees, joining clubs with fellow owners, attending regular gatherings to swap stories and product information and buying related paraphernalia such as jackets, hats and coffee mugs.

Customer loyalty is clearly a rare and valuable resource; in addition, it is difficult to imitate and substitute. When a company becomes a key source of identity and the main provider of symbols for community members, its symbiotic relationship with the target community is almost impossible for other companies to imitate. Rather, it would be easier for competitors or imitators to develop their own relationship-based intangible assets with other communities than to attempt to attract community members linked to the focal firm. This situation reinforces the differentiation across firms and makes any competitive advantage more sustainable.

Although identity-creation CFS make resources more valuable to both the focal firm and the target community, which are increasingly rare with greater customization of the identity-based products/services and thus less imitable and substitutable, they also increase the co-dependencies of the firm and the community. If broader market conditions change, and a shift in the resource base is needed, these co-dependencies might transform into disadvantages. Economies of scale could force the focal firm to pursue growth strategies, such that it must manage diverse customer bases that span physical locations and product categories. A larger customer base increases the probability of conflicting values. The focal firm then faces a trade-off: switch its CFS approach or constrain its growth options. The experience of Ben \& Jerry's exemplifies this concern (Cohen and Greenfield, 1998). Initially the company only used milk from Vermont cows, supported local education and engaged in community-based interactions with local farmers. Such values generated a committed customer base and the emergence of communities identified with values such as tolerance, freedom and anti-conformism. Consuming Ben \& Jerry’s ice cream meant belonging to local communities that shared such values. When Ben \& Jerry's became a multinational corporation, and then was purchased by the global consumer products giant Unilever, it changed its focus from local connectedness to global responsibility. Some relationship-based intangible assets built through its initial approach inevitably were lost.

\section{Selection of CFS}

Choosing which community-focused approach to implement is a complex task that depends on multiple sources of exogenous variation across firms (e.g. institutional environments, sectors, size, firm profile). For tractability and consistency with our framework, we focus on ex ante differences (i.e. before CFS are implemented) across firms' customer bases to explore how heterogeneity in the identities of firms' customer bases affects their choice of CFS. ${ }^{2}$ Thus we analyse the identities of the focal firm's customer base along two dimensions: the level of identity heterogeneity and the level of identity salience. 
We define identity heterogeneity as the degree of dispersion in the values of the communities to which the focal firm's customers belong. A focal firm might face a high level of identity heterogeneity if more diverse identities with potentially orthogonal values characterize the communities that form its customer base. Instead, identity heterogeneity is low if most customers belong to a single or a few communities with similar values. Identity heterogeneity likely correlates with the size of the customer base, such that large, diversified, multinational firms experience greater identify heterogeneity.

Identity salience refers to the relative importance of the meaning derived from community participation for each member's self-structure (Bhattacharya and Sen, 2003; Kleine et al., 1993). A high level of identity salience exists when the customer base represents communities that contribute significantly to the formation of their members' personal identity. In contrast, low identity salience indicates that only a small part of the personal identity of the firm's customers is attributable to their community participation. Consistent with our definition of community, we are only interested in identity salience beyond a certain threshold level. Identity salience should be associated with the size of the community; very large communities usually provide less identification for their members (Cohen, 1982).

Let us start by considering firms that confront a customer base (pre-adoption CFS) formed by fragmented identity communities with either low or high degrees of identity salience. When firms try to conform to several identities that normally do not align (Albert and Whetten, 1985), they cannot credibly commit to all the different values on which their target communities anchor their identities (Foreman and Whetten, 2002). Their commitment then is not credible, because it does not imply choice and investment irreversibility (Danneels, 2003). The focal company cannot exert a great deal of power over the identities of the target communities. In the presence of high identity heterogeneity then, neither identity-enhancing nor identity-creation CFS is a viable alternative.

The inability to control communities' identities is particularly costly when the focal firm's customer base has high identity salience, because the lack of congruence with the values of a particular community likely generates negative reactions from other communities' members (Hickman and Ward, 2007; Holt, 2002). In this case, the company is well advised to avoid engaging in CFS. Instead, if identity salience is low, mild ex ante actions and investments that reflect the firm's association with the communities' values might be beneficial. Weak identity salience implies a low need for comparison and confrontation (Tajfel and Turner, 1979), so customers should not respond negatively to a firm that shares and conforms to values that go beyond those of their own community. In this case, signalling CFS may be the best option.

Consider now the case in which the focal firm's customer base exhibits low identity heterogeneity. The focal firm can focus its investments on a limited number of homogeneous values. Insofar as most customers share the same (or similar) values, commitment does not produce any value conflict. The focal company exerts a strong influence on its target communit(ies); this power then grants community membership to the focal firm, fine-tunes its role as a provider of symbols and ultimately elicits reciprocal behaviour from community members (Chan and Li, 2010). However, when the customer base is characterized by high identity salience, their communities are autonomous and self-sufficient in creating values (Holt, 2002). Attempting to change these wellestablished values would be risky, because community members obtain most of their personal identity from those values and are not willing to give up any associated identity (Murray and Ozanne, 1991). The focal firm should share and adapt to the set of established values, and it likely cannot provide new identities to customers, especially during initial value-based interactions. In the presence of a high identity salience, customers thus are likely to reject 'marketers' dominance' 
or a cultural code created just by marketers (Ozanne and Murray, 1995). Firms are better advised to achieve high congruence through identity-enhancing CFS.

In contrast, when the customer base comprises communities with homogeneous values and low levels of identity salience, there is room for the firm to generate new combinations of community values and provide new identities. Ducati represents a good example. Before 1996, the customer base consisted of bikers from different communities with rather homogeneous values and weak identity salience. Domenico Minoli transformed the customer base by imposing new identities built around the motorbike. By 2000, a Ducati community existed, in which most bikers identified with the product and the brand, rather than with other values (Gavetti, 2001).

\section{Concluding remarks}

This article systematizes knowledge about the business opportunities firms might seize and the challenges they must face to build and sustain competitive advantages in a societal configuration characterized by the increasing presence of communities as providers of identity. We first describe the fundamental traits of such communities and the process that leads to identity provision; we then propose a taxonomy of the strategies that firms can implement to interact with communities of (potential) customers. Our analysis explains how firms establish and maintain a competitive advantage by fine-tuning their interactions with groups or communities to which (some of) their customers belong.

Theoretically, we contribute to extant literature by linking two fields of research that generally coexist as separate silos: strategy and social identity theory. Our hybrid approach provides a better understanding of why some firms are more likely to adopt a certain community-focused approach. Most important, we explain competitive advantage through identity-based links with external communities. Although strategic interactions between firms and communities have been the focus of both institutional theory (e.g. Marquis et al., 2007) and stakeholder theory (e.g. Dunham et al., 2006), our study offers an extended characterization of the dynamics that identity-based interactions generate and their potential for value creation. In addition, our combined framework revisits, through a different path, some well-investigated issues in management research, including corporate social responsibility (CSR) activities (e.g. McWilliams and Siegel, 2001), social movements and consumer boycotts (e.g. Reid and Toffel, 2009) and brand communities (e.g. Muniz and O’Guinn, 2001). These different traditions could be brought under the same theoretical umbrella namely, an identity-based model of strategic interactions.

Our work also has some important implications for practitioners. Our proposed taxonomy identifies an ample CFS spectrum that firms can pursue; for each type, we also suggest appropriate actions and policies (i.e. pure advertising, philanthropy, fundraising, organization of events), the required commitment intensity (i.e. level of financial and human resources dedicated to CFS) and the appropriate locus of investment within the company.

Because CFS strongly impinge on values, managers involved in implementing such strategies should attend to the congruence of their actions and policies with supported community values. A values misalignment between allegedly supported values and those values reflected in or imputed to the firm's actions and activities (Gardberg and Fombrun, 2006) not only impairs community trust (Kay, 2006; Palazzo and Basu, 2007) and destroys relationship-based intangible assets derived from CFS but also can translate into hostility and consumer boycotts (Aaker, 2004; Breen, 1988). The simplest manifestation of this backlash occurs when a firm openly violates community values (Palazzo and Basu, 2007), such as when a company claims to support and share environmental values but then employs highly polluting processes or releases toxic products. 
This consideration implies that CFS impose some limitations on other strategic choices, which managers must account for fully. Compared with a competitor that does not follow CFS, a participating firm suffers from a limited array of strategic tools, because it must exclude all actions that generate conflicts with the values and symbols of its target community. For example, its pricing decisions likely experience additional constraints, because high prices seem to contradict the firm's engagement with the founding values of a community, especially if they have a strong social connotation. As other examples, a firm cannot perform R\&D in profitable technological areas (e.g. stem cells) if some of its community's political and religious values conflict with such research; it might not be able to enter alliances and joint ventures with potential partners that appear to contradict its target community's values. In summary, a practical implication of our analysis reveals that firms pursuing CFS are well advised to pay particular attention to specific areas of the value chain at which interactions with communities are most visible (e.g. branding and marketing strategies). Yet they also must pursue general coherence across the different activities and functions essential to the implementation of CFS (e.g. R\&D, production, human resources).

Several important theoretical aspects and extensions of our framework do not appear in our analysis, for tractability reasons, and we hope further research will address them. Two deserve particular mention. First, our framework does not address the implications of CFS for industry life cycles. A rising trend in research in economics (Klepper and Thompson, 2006) and sociology (Carroll, 1985) describes industry evolution according to the life and death dynamics of various market niches. Additional work might relate our proposed taxonomy to these new lines of research (e.g. specialists vs generalists). Second, CFS has implications for the organizational structure of the company and corporate strategy. The way a firm grows (e.g. internationalization, diversification) may be constrained by or affect its community-focused approach. The effective implementation of CFS, especially with strong, value-based commitment, requires conditional congruence, such that all firm-community value links appear coherent. Firms pursuing either identity-enhancing or identity-creation CFS thus might need more control across the entire value chain - or even a different organizational structure.

A better understanding of this phenomenon is unlikely to progress without more comprehensive data. We thus call for empirical approaches, perhaps including ad hoc surveys of top managers and executives, that can measure constructs such as identity commitment, salience and heterogeneity. Secondary data sources could provide important empirical tests as well. Researchers might relate objective firm financial performance with the type and level of firm commitment to CFS, while controlling for standard covariates. An event study methodology also could estimate how financial markets respond to positive and negative events associated with targeting communities of customers, such as sponsorships, human resource interventions, donations, investments in philanthropic causes, or community-oriented advertising campaigns, as well as conflicts between firms and communities (e.g. strikes, boycotts, public statements).

Finally, we acknowledge the possibility of cases in which communities and their shared identities exist because the focal firm exists, without any explicit or voluntary intention by the firms to build these identities. The company neither embraces the values and beliefs of the target community nor intentionally seeks a competitive advantage through interactions with the community. For example, some firms prompt customer boycotts, which can give rise to social movements, activist groups, or communities whose members' self-definitional needs are fulfilled by their anticompany stance (Ingram et al., 2010; King, 2008). The Anti-Coca Cola Struggle Committee in India represented a response to the excessive extraction of groundwater by a bottling plant; an anti-Walmart movement has arisen as a consequence of the retailer's alleged lack of healthcare 
coverage for its employees. In these cases, the firm must devise actions and tactics to defend its image and reputation, as demonstrated by Reid and Toffel (2009) and Ingram et al. (2010).

\section{Acknowledgements}

The authors thank Jean-Philippe Bonardi, Rodolphe Durand, Mark Thomas Kennedy, David Levy, Serden Ozcan, Dev Jennings (Editor), three anonymous reviewers of this journal and seminar participants at Aarhus Business School, Bocconi University, IESE Business School, Imperial College, Cass Business School, the 2008 Annual Conference of the Academy of Management and the 2010 Organization Studies Summer Workshop for their comments and suggestions on previous drafts. The usual disclaimer applies.

\section{Funding}

Financial support from the Ministry of Science and Innovation (ECO2009-08308; ECO2010-09184-E) is gratefully acknowledged.

\section{Notes}

1. Sometimes a community is an overly broad and coarse representation of a unique identity provider, such that communities might encompass richer, more complex structures, with different and distinct subcultures, tribes and subcommunities (Hoffman, 1999; Maffesoli, 1996). Hoffman and Bertels (2010) illustrate a high degree of complexity and fragmentation within the broadly defined 'environmentalist community'. Although we loosely refer to target communities, the appropriate level of analysis thus is the subcommunity.

2. This discussion assumes that the identity composition of a firm's customer base precedes its choice of CFS. We acknowledge that in some cases, both the CFS choice and the firm's customer base are endogenous and interrelated. A start-up company might choose a specific community-focused approach because it wants to target customers of a given community. In this case, rather than a causal relationship, our discussion implies a correlation.

\section{References}

Aaker, D. J. (2004) 'Leveraging the Corporate Brand', California Management Review 46(3): 6-18.

Albert, S. and Whetten, D. A. (1985) 'Organizational Identity', in L. L. Cummings and B. M. Staw (eds) Research in Organizational Behavior, pp. 263-95. Greenwich, CT: JAI Press.

Algesheimer, R., Dholakia, D. M. and Herrmann, A. (2005) 'The Social Influence of Brand Communities: Evidence from European Car Clubs’, Journal of Marketing 69(3): 19-34.

Anthony, D. (2005) 'Cooperation in Microcredit Borrowing Groups: Identity, Sanctions, and Reciprocity in the Production of Collective Goods', American Sociological Review 70(3): 496-515.

Arnould, E. J. and Thompson, C. J. (2005) 'Consumer Culture Theory (CCT): Twenty Years of Research', Journal of Consumer Research 31(4): 868-882.

Ashforth, B. and Mael, F. (1989) 'Social Identity Theory and the Organization', Academy of Management Review 14(1): 20-39.

Barnett, M. and Salomon, R. (2006) 'Beyond Dichotomy: The Curvilinear Relationship between Social Responsibility and Financial Performance’, Strategic Management Journal 27(11): 1101-22.

Barney, J. B. (1991) 'Firm Resources and Sustained Competitive Advantage', Journal of Management 17(1): 99-120.

Bhattacharya, C. B. and Sen, S. (2003) 'Consumer-Company Identification: A Framework for Understanding Consumers' Relationships with Companies', Journal of Marketing 67(2): 76-88.

Breen, T. H. (1988) 'Baubles of Britain: The American and Consumer Revolution of the Eighteenth Century', Past and Present 119(1): 73-104.

Briscoe, F. and Safford, S. (2008) 'The Nixon-in-China Effect: Activism, Imitation, and the Institutionalization of Contentious Practices', Administrative Science Quarterly 53(3): 460-91. 
Business Wire (2000) ‘Greenpeace Activists Journey to “Ground Zero” for Global Warming’, Launch Arctic Action Web Site: $1640-1$.

Calvano, L. (2008) 'Multinational Corporation and Local Communities: A Critical Analysis of Conflicts', Journal of Business Ethics 82(4): 793-805.

Carroll, G. R. (1985) 'Concentration and Specialization: Dynamics of Niche Width in Population of Organizations', American Journal of Sociology 90(6): 1262-83.

Castells, M. (2000) End of Millennium, The Information Age: Economy, Society and Culture, Vol. III. Cambridge, MA and Oxford: Blackwell.

Chan, K. W. and Li, S. Y. (2010) 'Understanding Consumer-to-Consumer Interactions in Virtual Communities: The Salience of Reciprocity', Journal of Business Research 63(9-10): 1033-40.

Cohen, A. P. (1982) Belonging: Identity and Social Organization in British Rural Cultures. Manchester: Manchester University Press.

Cohen, A. P. (1985) The Symbolic Construction of Community. London: Tavistock.

Cohen, B. and Greenfield, J. (1998) Ben \& Jerry's Double Dip: How to Run a Values-Led Business and Make Money Too. New York: Simon and Schuster.

Combs, J. G., Michael, S. C. and Castrogiovanni, G. J. (2009) 'Institutional Influences on the Choice of Organizational Form: The Case of Franchising', Journal of Management 35(5): 1268-90.

Cova, B. and Cova, V. (2002) 'Tribal Marketing: The Tribalisation of Society and its Impact on the Conduct of Marketing’, European Journal of Marketing 36(5): 595-620.

Cow, G. and Allan, G. (1994) Community Life. An Introduction to Local Social Relations. Hemel Hempstead: Harvester Wheatsheaf.

Danneels, E. (2003) 'Tight-Loose Coupling with Customers: The Enactment of Customer Orientation', Strategic Management Journal 24(6): 559-76.

Di Maggio, P. J. and Powell, W. W. (1983) 'The Iron Cage Revisited: Institutional Isomorphism and Collective Rationality in Organization Fields', American Sociological Review 48(2): 147-60.

Donaldson, T. and Preston, L. E. (1995) 'The Stakeholder Theory of the Corporation: Concepts, Evidence and Implications', Academy of Management Review 20(1): 65-91.

Dunham, L., Freeman, R. E. and Liedtka, J. (2006) 'Enhancing Stakeholder Practice: A Particularized Exploration of Community’, Business Ethics Quarterly 16(1): 23-42.

Dutton, J., Dukerich, J. and Harquail, C. (1994) 'Organizational Images and Members' Identification', Administrative Science Quarterly 39(2): 239-63.

Edges, L. (2010) 'Seacoast Surfers Hit the Wave in Winter'. Available at: www.seacoastonline.com/ articles/20100104-NEWS-1040333.

Elsbach, K. and Bhattacharya, C. (2001) 'Defining Who You Are and Why You're Not: Organizational Disidentification and The National Rifle Association', Organization Science 12(4): 393-413.

Etgar, M. (2008) 'A Descriptive Model of the Consumer Coproduction Process', Journal of the Academy of Marketing Science 36(1): 97-108.

Fireman, B. and Gamson, W. A. (1979) 'Utilitarian Logic in the Resource Mobilization Perspective', in J. D. McCarthy and M. N. Zald (eds) The Dynamics of Social Movements: Resource Mobilization, Social Control and Tactics, pp. 8-44. Cambridge: Winthrop.

Foreman, P. and Whetten, D. (2002) 'Members' Identification with Multiple-Identity Organizations', Organization Science 13(6): 618-35.

Forest, R., Casadesus-Masanell, R. and Freier, D. (2003) 'Patagonia', Harvard Business School Cases, 18 March.

Fournier, S. (1998) 'Consumers and their Brands: Developing Relationship Theory in Consumer Research', Journal of Consumer Research 24(4): 343-73.

Fournier, S. and Lee, L. (2009) ‘Getting Brand Communities Right', Harvard Business Review 87(4): 105-11. Freeman, E. (1984) Strategy Management: A Stakeholder Approach. Boston, MA: Pitman.

Frooman, J. (1999) 'Stakeholder Influence Strategies', Academy of Management Review 24(2): 191-206.

Gardberg, N. A. and Fombrun, C. J. (2006) 'Corporate Citizenship: Creating Intangible Assets across Institutional Environments', Academy of Management Review 31(2): 329-46.

Gavetti, G. (2001) ‘Ducati’, Harvard Business School Case, 701132. 
Gergen, K. (1991) The Saturated Self: Dilemmas of Identity in Contemporary Life. New York: Basic Books. Godfrey, P. C. (2005) 'The Relationship between Corporate Philanthropy and Shareholder Wealth: A Risk Management Perspective', Academy of Management Review 30(4): 777-98.

Gordon, R. A. (1996) 'Impact of Ingratiation on Judgments and Evaluations: A Meta-Analytic Investigation', Journal of Personality and Social Psychology 71(1): 54-70.

Greenwood, R. and Suddaby, R. (2006) 'Institutional Entrepreneurship in Mature Fields: The Big Five Accounting Firms', Academy of Management Journal 49(1): 27-48.

Harrison, S. and Corley, K. (2010) 'Clean Climbing, Carabiners, and Cultural Cultivation: Developing and Open-Systems Perspective of Culture’, Organization Science 20(2): 1-22.

Heckathorn, D. D. (1996) 'The Dynamics and Dilemmas of Collective Action', American Sociological Review 61(2): 250-77.

Hickman, T. and Ward, J. (2007) 'The Dark Side of Brand Community: Inter-Group Stereotyping, Trash Talk and Schadenfreude', Advances in Consumer Research 34: 314-19.

Hitlin, S. (2003) 'Values as the Core of Personal Identity: Drawing Links between Two Theories of Self', Social Psychology Quarterly 66(2): 118-37.

Hitlin, S. and Pillavin, J. A. (2004) 'Values: Reviving a Dormant Concept', Annual Review of Sociology 30: 359-93.

Hoffman, A. J. (1999) 'Institutional Evolution and Change: Environmentalism and the US Chemical Industry', Academy of Management Journal 42(4): 351-71.

Hoffman, A. and Bertels, S. (2010) 'Who is Part of the Environmental Movement? Assessing Network Linkages between NGOs and Corporations', in T. Lyon (ed.) Good Cop Bad Cop: Environmental NGOs and their Strategies toward Business, pp. 48-69. Washington, DC: Resources for the Future Press.

Hogg, M. and Terry, D. (2000) 'Social Identity and Self-Categorization Processes in Organizational Contexts', Academy of Management Review 25(1): 121-40.

Holt, B. H. (2002) 'Why Do Brands Cause Troubles? A Dialectical Theory of Consumer Culture and Branding', Journal of Consumer Research 29(1): 70-90.

Homburg, J., Wieseke, W. and Hoyer, D. (2009) 'Social Identity and the Service-Profit Chain', Journal of Marketing 73(3): 38-54.

Ingram, P., Yue, L. Q. and Rao, H. (2010) 'Trouble in Store: Probes, Protests, and Store Openings by Wal-Mart, 1998-2007’, American Journal of Sociology 116(1): 53-92.

Julian, S. D., Ofori-Dankwa, J. C. and Justis, R. T. (2008) 'Understanding Strategic Responses to Interest Group Pressures’, Strategic Management Journal 29(9): 963-84.

Kay, M. (2006) 'Strong Brands and Corporate Brands', European Journal of Marketing 40(7): 742-60.

Keller, K. and Aaker, D. (1998) 'Corporate-Level Marketing: The Impact of Credibility on a Company's Brand Extensions', Corporate Reputation Review 1(4): 356-78.

King, B. G. (2008) 'A Political Mediation Model of Corporate Response to Social Movement Activism', Administrative Science Quarterly 53(3): 395-421.

King, B. G. and Soule, S. A. (2007) 'Social Movements as Extra-Institutional Entrepreneurs: The Effect of Protest on Stock Price Returns', Administrative Science Quarterly 52(3): 413-42.

Kleine, R. E., Kleine, S. S. and Kernan, J. B. (1993) 'Mundane Consumption and the Self: A Social-Identity Perspective', Journal of Consumer Psychology 2(3): 209-35.

Klepper, S. and Thompson, P. (2006) 'Submarkets and the Evolution of Market Structure', Rand Journal of Economics 37(4): 861-86.

Kumar, K. (2005) From Post-Industrial Society to Post-Modern Society: New Theories of the Contemporary World. Oxford: Blackwell.

Lanagan, D. (2009) 'Surfing in the Third Millennium: Commodifying the Visual Argot', Australian Journal of Anthropology 13(3): 283-91.

Laraña, E., Johnston, H. and Gusfield, J. R. (1994) New Social Movements: From Ideology to Identity. Philadelphia, PA: Temple University Press.

Lee, D. and Newby, H. (1983) The Problem of Sociology: An Introduction to the Discipline. London: Unwin Hyman. 
Lev, B., Petrovits, C. and Radhakrishnan, S. (2010) 'Is Doing Good Good for You? How Corporate Charitable Contributions Enhance Revenue Growth’, Strategic Management Journal 31(2): 182-200.

Lyotard, J. F. (1984) The Postmodern Condition. Minneapolis: Minnesota University Press.

McAlexander, J. H., Schouten, J. and Koenig, H. (2002) ‘Building Brand Community’, Journal of Marketing 66(1): 38-54.

McWilliams, A. and Siegel, D. (2001) 'Corporate Social Responsibility: A Theory of the Firm Perspective', Academy Management Review 26(1): 117-27.

Maffesoli, M. (1996) The Time of the Tribes. London: Sage.

Marini, M. M. (2000) 'Social Values and Norms', in E. F. Borgatta and R. J. V. Montgomery (eds) Encyclopedia of Sociology, pp. 2828-40. New York: Macmillan.

Marquis, C., Glynn, M. A. and Davis, G. F. (2007) ‘Community, Isomorphism and Corporate Social Action', Academy of Management Review 32(3): 925-45.

Mullen, B., Brown, R. and Smith, C. (1992) 'Ingroup Bias as a Function of Salience, Relevance, and Status - An Integration', European Journal of Social Psychology 22(2): 103-22.

Munir, K. A. and Philips, N. (2005) 'The Birth of the "Kodak Moment”: Institutional Entrepreneurship and Adoption of New Technologies', Organization Studies 26(11): 1665-87.

Muniz, A. and O’Guinn, T. (2001) 'Brand Community', Journal of Consumer Research 27(4): 412-32.

Murray, J. B. and Ozanne, J. L. (1991) 'The Critical Imagination: Emancipatory Interests in Consumer Research', Journal of Consumer Research 18(2): 129-44.

O’Hern, M. and Rindfleisch, A. (2009) 'Customer Co-Creation: A Typology and Research Agenda', in N. K. Malholtra (ed.) Review of Marketing Research, Vol. 6, pp. 84-106. Armonk, NY: M. E. Sharpe.

O’Reilly, C., Chatman, J. and Caldwell, D. (1991) 'People and Organizational Culture: A Profile Comparison Approach to Assessing Person-Organization Fit', Academy of Management Journal 34(3): 487-516.

Ozanne, J. L. and Murray, J. B. (1995) 'Uniting Critical Theory and Public Policy to Create the Reflexively Defiant Consumer', American Behavioral Scientist 38(4): 516-25.

Palazzo, G. and Basu, K. (2007) 'The Ethical Backlash of Corporate Branding', Journal of Business Ethics 73(4): 333-46.

Reid, E. M. and Toffel, M. W. (2009) 'Responding to Public and Private Politics: Corporate Disclosure of Climate Change Strategies’, Strategic Management Journal 30(11): 1157-78.

Rowley, T. J. and Moldoveanu, M. (2003) 'When Will Stakeholder Groups Act? An Interest and IdentityBased Model of Stakeholder Group Mobilization', Academy of Management Review 28(2): 204-19.

Salancik, G. R. (1977) ‘Commitment is too Easy’, Organizational Dynamics 6(3): 62-80.

Schau, H. J., Muniz, A. M. and Arnould, E. J. (2009) 'How Brand Community Practices Create Value', Journal of Marketing 73(5): 30-51.

Schouten, J. and McAlexander, J. (1995) 'Subcultures of Consumption: An Ethnography of the New Bikers', Journal of Consumer Research 22(1): 43-61.

Schouten, J., McAlexander, J. and Koenig, H. (2007) 'Transcendent Customer Experience and Brand Community’, Journal of the Academy Marketing Science 35(3): 357-68.

Schwartz, S. H. (1994) 'Are There Universal Aspects in the Structure and Content of Human Values?', Journal of Social Issues 50(4): 19-45.

Scott, W. R. (2005) 'Institutional Theory: Contributing to a Theoretical Research Program', in K. G. Smith and M. A. Hitt (eds) Great Minds in Management: The Process of Theory Development, pp. 460-85. Oxford: Oxford University Press.

Selznick, P. (1957) Leadership in Administration. New York: Harper and Row.

Shih, M., Pittinsky, T. L. and Ambady, N. (1999) 'Stereotype Susceptibility: Identity Salience and Shifts in Quantitative Performance', Psychological Science 10(1): 80-3.

Smith, M. B. (1991) Values, Self and Society: Towards a Humanist Social Psychology. New Brunswick, NJ: Transaction.

Stets, J. E. and Burke, P. J. (2000) 'Identity Theory and Social Identity Theory’, Social Psychology Quarterly 63(3): 224-37.

Tajfel, H. and Turner, J. C. (1979) 'An Integrative Theory of Intergroup Conflict', in W. G. Austin and S. Worchel (eds) The Social Psychology of Intergroup Relations. Monterey, CA: Brooks-Cole. 
Taylor, B. (2007) 'Surfing into Spirituality and a New, Aquatic Nature Religion', Journal of the American Academy of Religion 75(4): 923-51.

Taylor, C. (1989) Sources of the Self: The Making of the Modern Identity. Cambridge, MA: Cambridge University Press.

Turner, J. C. and Tajfel, H. (1986) 'The Social Identity Theory of Intergroup Behavior', in S. Worchel and W. Austin (eds) Psychology of Intergroup Relations, pp. 7-24. Chicago, IL: Nelson-Hall.

Vattimo, G. (1992) The Transparent Society. Cambridge: Polity Press.

Wang, H. L., Choi, J. P. and Li, J. T. (2008) 'Too Little or Too Much? Untangling the Relationship between Corporate Philanthropy and Firm Financial Performance', Organization Science 19(1): 143-59.

Weick, K. E. (1995) Sensemaking in Organizations. Beverly Hills, CA: Sage.

Wood, D. J. and Jones, R. E. (1995) 'Stakeholder Mismatching: A Theoretical Problem in Empirical Research on Corporate Social Performance’, International Journal of Organizational Analysis 3(3): 229-67.

Zucker, L. G. (1986) 'Production of Trust: Institutional Sources of Economic Structure', Research in Organizational Behavior 8(1): 53-111.

\section{Author biographies}

Andrea Fosfuri is Professor of Management at the Department of Business Administration of University Carlos III, Madrid, and has held visiting appointments at Boston University, Carnegie Mellon University and Bocconi University. His current research projects examine the internal organization of licensing activity, the interaction between product and technology strategies, the determinants and implications of 'green' patenting and the virtues and limitations of community-focused strategies. Address: Universidad Carlos III de Madrid, Department of Business Administration, Calle Madrid 126, Getafe 28903, Madrid, Spain. [email: andrea. fosfuri@uc3m.es]

Marco S. Giarratana is Associate Professor at the Department of Management of Bocconi University, Milan and a member of the CROMA research institute. Marco holds a PhD in Management and Economics from Sant'Anna School of Advanced Studies (2003, Pisa, Italy) and was previously a faculty member of the Universidad Carlos III de Madrid (2003-2011). Marco has published several articles on two research lines: (1) knowledge spillovers and geography; (2) technology, product and marketing strategy. Address: Bocconi University, Management Department, Via Roentgen 1, 20136 Milan, Italy. [email: mgiarra@gmail.com]

Esther Roca is an Assistant Professor of Management at the Department of Business Administration of University Carlos III, Madrid. Her research lies at the intersection between philosophy, sociology and management. Recently, she has focused on developing a critical analysis of business ethics and on studying the interactions between firms and communities. Address: Universidad Carlos III de Madrid, Department of Business Administration, Calle Madrid 126, Getafe 28903, Madrid, Spain. [email: esther.roca@uc3m.es] 